https://doi.org/10.18485/iipe_postsovjet.2021.ch9

Иван Алексејевич Војт ${ }^{1}$

\title{
ФОРМИРАЊЕ ПРИДЊЕСТРОВСКЕ ИДЕНТИЧНОСТИ У УСЛОВИМА МНОГОНАЦИОНАЛНЕ ЗАЈЕДНИЦЕ
}

\begin{abstract}
Anacmракт: У чланку се разматра проблем постојања и развоја придњестровске идентичности. Различита мишљења и термини, којима се одређује њен карактер, стимулисали су аутора да одговори на следећа питања: како се и када формирала придњестровска идентичност: који фактори су деловали на њено формирање; какве је врсте та идентичност етничка, регионална, лингвистичка или друга. Без обзира на дискутабилност проблема, аутор долази до закључака да се формирање придњестровске идентичности одвијало током деценија, али се у условима политичке стабилност у региону развијало споро. Када се пак појавила опасност, претња од стране непријатеља, страх да већина оних вредности које су гајене деценијама може бити уништена од стране прорумунски расположених националиста Молдавије, процес учвршћења придњестровске идентичности добио је нови подстрек и наставља да се развија до данас. Придњестровци теже да добију признање своје државности од светске заједнице, пре свега, ради заштите својих етничких, социјално-политичких и националних интереса и привилегија.
\end{abstract}

Кључне речи: молдавско-придњестровски конфликт, придњестровска идентичност, придњестровски народ, Придњестровска Молдавска Република.

У неким радовима историчара, политиколога и социолога истиче се хипотеза о томе да је молдавско-придњестровски конфликт у свом већем делу настао као резултат сукобљавања националних идентичности -

\footnotetext{
${ }^{1}$ Иван Алексејевич Војт, предавач на катедри политикологије и државног управљања Придњестровског државног универзитета Т. Г. Шевченко, (г. Тираспољ, Придњестровска Молдавска Република), voitia_84@mail.ru
} 
молдавске и румунске. На почетку 90-их година 20. века придњестровски Молдавци подржали су стварање Придњестровске Молдавске Републике (ПМР), пошто су се надали да ће путем образовања сопствене републике сачувати своју молдавску идентичност, молдавски менталитет, своју уникатну молдавску културу и молдавски језик. И на том плану противречности између Придњестровља и Молдавије појавиле су се нипошто не по линији „придњестровски интернационалисти - молдавски националисти“, већ по линији „молдавизам Придњестроваца прорумунски шовинизам кишињевских власти" [Феномен Приднестровья, 2003: c. 122].

Сагласно мишљењу других научних и политичких експерата, молдавскопридњестровски конфликт оцењује се као језички конфликт између општина молдавског и руског говора. Неки истраживачи, држећи се ове хипотезе, одредили су га као конфликт између етничких Молдаваца и етничких Руса који сви живе у Молдавији [Скворцова, 2003: с. 59]. Логично би било претпоставити да се опозиција званичном статусу руског језика сукобила са интересима Руса, узимајући у обзир да су у већини совјетских република Руси представљали најзначајнију групу нематичног становништва. Тај модел био је примењен и на Молдавију и Придњестровље. Као резултат, неки експерти указали су на само један од узрока конфликта - нехтење Руса да се одрекну својих некада привилегованих позиција у савезним републикама, које је подржавано нехтењем Русије да изгуби своју власт у тим републикама [Кирошка, 1996: с. 12]. Руска штампа и Државна Дума, који су представљали Придњестровце као бојну руску мањину која се бори против шовинистичког молдавског национализма, подржавали су такво мишљење [Скворцова, 2003: с. 59].

На тај начин придњестровски конфликт био је описан као етнички, у којем се сукобљавају две етничке групе. Ипак, као што је приметио амерички истраживач Стјуарт Кауфман, то није био једноставно конфликт између Молдаваца и Руса, „... јер у становништву придњестровског региона преовлађивала је група која је укључивала русификоване Молдавце и Украјинце, такође и Русе“. С. Кауфман сматра да је придњестровско руско становништво било не етничка група већ пре „коалиција уједињених етничких интереса који су се супротстављали молдавским етничким интересима" [Скворцова, 2003: с. 59]. На тај начин, његов закључак се заснивао на томе да је свака супротстављена страна имала своју представу 
о историјском доминирању друге групе у различитим периодима у прошлости, и проблеми етничког симболизма, као што су застава, језик и алфабет, нашли су се на оштрици политичког програма. И више од тога, лидери сваке општине изјавили су да су се сукобили са дилемом безбедности, реалне претње уништења: Молдавци су сматрали да ће даље преовладање руског језика довести до ишчезавања њиховог етноса, рускоговорећи су мислили да ће давање приоритетног статуса молдавском језику и румунски триколор (под којим су Румуни наступали у време Другог светског рата) обновити шовинистичку политику Гвоздене гарде Румуније.

Мишљење о томе да молдавско-придњестровски конфликт није био више него политички (или је био непосредан резултат мобилизације елите) такође је нашло присталице, иако су га у другим радовима исти аутори карактерисали као етнички.

Као резултат свих горе наведених закључака и мишљења потребно је констатовати да они не објашњавају целину о конфликту између Придњестровља и Молдавије. Желели бисмо да истакнемо да су, сходно статистичким подацима, у 1989. години на почетку конфликта 39,9\% становништва Придњестровља чинили Молдавци, 28,3\% Украјинци и 25,4\% Руси [Феномен Приднестровья, 2003: с. 121]. Део Украјинаца и Молдаваца асимиловало се с Русима, што се не може рећи о тим групама у целини. Велики део тих група сачувао је свој језик, културне традиције и осећај припадности својим етносима. На тај начин, разноврсност карактеристика које су дате конфликту указује на то да нити једна од њих није савршена, и да је потребно тражење нових приступа.

Приступ истраживању са позиција проучавања идентичности био је већ искоришћен од неких научника, али њихова мишљења о томе какву заправо идентичност представља придњестровско становништво разилазила су се. Први пут је идеја о заједничкој идентичности била формулисана у Извештају № 13 Мисије ОСЦЕ у Молдавији, у новембру 1993. године. У њему се указивало да „јасан осећај сопствене придњестровске идентичности“ постоји у региону и да се „он заснива углавном не на идентичности, пошто га поседују не само Словени, већ и већина етничких Молдаваца“ [Доклад №13 Миссии ОБСЕ в Молдове, 1993]. Ванда Дреслер је употребила термин „посебна дњестровска идентичност“, Клименс Бушер - „одређена идентичност“, а Пол Колсто и Андреј Малигин - „неодређена, али нипошто не мање опипљива 
идентичност“, која „пролази кроз етничке границе“ и „обавезана је више историјом и географијом него идеологијом", док истовремено као „обележја културне идентичности, као што је језик, такође имају своју улогу“ [Скворцова, 2003: с. 60]. Нужно је приметити да су неки молдавски политичари такође признали да се Придњестровље разликује од основне Молдавије, мада они и нису користили термин „идентичност“. Николаје Киртоака, саветник председника Републике Молдавије за ратна питања у периоду ратног конфликта у Придњестровљу, касније је сумирао да „област на истоку од реке има карактеристичне црте“, а бивши председник Републике Молдавије Петру Лучински истакао је да је Придњестровље имало своје особености које су захтевале да му се да „специјални статус“.

Опште признање постојања придњестровске идентичности, различита мишљења и термини којима се одређује њен карактер, стимулисали су покушај аутора да одговори на следећа питања:

- Како се и када формирала придњестровска идентичност, као резултат формирања придњестровског народа?

- Који фактори су утицали на њено формирање?

- Какве је врсте та идентичност - етничка, регионална, лингвистичка или друга?

- Колико је она снажна и дуготрајна и какве су могуће трајекторије њеног развоја?

Одговорити на сва ова питања доста је компликовано, али аутор и не сматра да изврши тај задатак у потпуности. Стога овај материјал може да послужи као основа за будуће дискусије.

Сам термин „идентичност“ тумачи се на разне начине. Дејвид Лејтин сматра да је „идентичност - категорија припадности, она може да се заснива на таквим различитим обележјима као што су пол, каста, класа“ [Laitin David, 1999: с. 81]. У том правцу одсуствује етничка компонента, али други аутори тврде да се идентичност формира од материјала добијеног у породици, општини, друштву, нацији. У том контексту важно је какав се тип идентичности разматра. Ако је то национална или етничка идентичност, онда се изграђује комплекс колективних властитих имена, језика, легенди, историје и других карактеристика, прихваћених као основних за колективно самоопредељење дате групе становништва на ограниченој територији, и треба говорити о „политици идентичности“. Стога, у широком смислу, 
идентичност укључује језик, културу, традиције, историју, политичке идеје и мишљења. Лице или група имају неколико идентичности: језичку, етничку, религиозну, националну, политичку и др., и оне не могу бити наслеђене, оне се стичу. Истовремено, идентичност је променљива под утицајем историјских, политичких и културних процеса. Стога је формирање идентичности дуготрајан процес, а његове трајекторије могу не једном да се мењају. Веома важна компонента идентичности је то да чланови групе поседују осећај припадности датој идентичности.

Ако Придњестровци имају заједничку идентичност, какав је онда mun те идентичности? Она може да буде територијална и регионална, заснована на чињеници да река Дњестар дели Придњестровску Молдавску Републику од Републике Молдавије (са изузетком Бендера и околних села) и да је њена политичка историја била различита од Молдавије све до 1940. године. С друге стране, Придњестровље до 1990. године никада није постојало као административна област у садашњим границама. Значи ли то да се регионална идентичност почела формирати тек од 1989. године? Који су се у том случају фактори налазили иза придњестровске идентичности?

Да, Придњестровље је било класична пригранична територија. У стара времена овде су се смењивали различити народи. У средњем веку земље дуж леве обале Дњестра, издељене између Пољско-литванске уније и Кримских Татара, биле су слабо насељене, посебно у јужном делу. Прекретни моменат у историји Придњестровског региона било је његово укључење у састав Руске империје на почетку 18. века, што је за собом повукло активну колонизацију. Становништво је пристизало како са истока, тако и са запада. У саставу Империје дата територија остајала је током готово 130 година до бољшевичке револуције и стварања Украјинске ССР, која је постала део СССР. У Украјинској ССР Придњестровски регион налазио се у саставу аутономије - Молдавске Аутономне ССР. Ипак, кроз двадесет и нешто година ова област је изведена из састава Украјине и у 1940. години заједно са делом Бесарабије саставила је Молдавску Совјетску Социјалистичку Републику. У време Великог отаџбинског рата та територија, коју је окупирала румунска армија, ушла је у окупациону зону „Транснистрија“, која се простирала у међуречју Дњестра и Јужног Буга. МССР је била обновљена у својим границама у 1944. години и постојала је у том облику до 1991. 
Треба истаћи да нема никаквих сведочанстава за то да је становништво Придњестровља икада протестовало против ових доста честих промена, са изузетком немачко-румунске окупације периода Другог светског рата. Од почетка 19. века становништво краја било је етнички неједнородно, представљено у основи трима великим етничким групама (Украјинцима, Молдавцима, Русима), од којих ниједна није чинила већину.

Због честих политичких промена и етничке политике власти ниједна од основних етничких група није се осећала власником ове територије. При царизму одсуствовао је посебан приступ поданицима који су исповедали православље. Стога су се Молдавци, Руси и Украјинци налазили у једнаким условима: већина њих били су једноставно сељаци који су говорили на различитим језицима и радили на земљама разних спахија. Руски језик преовладавао је у немногобројним градовима у основи у административној сфери, у црквама и школама. После укључења Придњестровског региона у састав Украјинске ССР почела је украјинизација, и већина школа је била украјинизована.

У 1924. години, по одлуци руководства СССР-а, на територији источно од Дњестра била је створена Молдавска Аутономна Совјетска Социјалистичка Република (МАССР). С етничке тачке гледишта овај корак био је неоправдан, пошто су Молдавци чинили не више од $30 \%$ становништва. Али, стварање републике објашњавало се не тежњом да се подржи развој молдавског етноса, већ пре геополитичким интересима: постојање Молдавске републике требало је да служи као аргумент у борби СССР-а за прикључење Бесарабије. Упоредо с другим републикама Совјетска Молдавија постала је део политике „коренизације“, која се састојала у учвршћењу молдавског етничког елемента у комунистичкој партији и у државном апарату, отварању молдавских школа и публикацији новина на молдавском језику. Као резултат те трансформације почели су да осећају тешкоће Украјинци, пошто су украјинске школе, новине, установе почеле постепено да се затварају.

Ипак, општи резултати политике коренизације у МАССР нису оправдали очекивања. У октобру 1927. године само 8\% сарадника централних републичких установа били су Молдавци и само 5\% су знали молдавски језик. До 1936. године удео Молдаваца у државним установама порастао је до 15\% [Скворцова, 2003: с. 61]. 
Још гори су испали резултати увођења молдавског језика: нису сви који су се идентификовали са Молдавцима могли да користе језик својих предака. И Молдавци су заузели у републици највиша места, а представницима других етничких група допале су „одговорне“ и „техничке“ дужности.

У августу 1940. године територија МАССР била је подељена између Украјинске и Молдавске републике. Нова република - Молдавска ССР укључивала је централни део бивше руске, затим румунске провинције Бесарабије. Разлика у нивоу развоја индустрије, пољопривреде, образовања и медицинских установа Придњестровља и Бесарабије била је запањујућа. На левој обали Бесарабију су сматрали као изузетно заосталу област, и осећај друге, различите идентичности опстајао је, без обзира на политичко уједињење. Молдавци леве обале диференцирали су се од деснообалних Молдаваца, а њихов језик имао је само мале сличности са стандардним румунским који је био уведен у Бесарабији у периоду између два рата. Интензивни контакти Молдаваца са другим етничким групама у Придњестровљу условили су за молдавски језик велики број позајмица из руског и украјинског.

Као што је познато, идентичност је производ социјалног обучавања, које спроводе такви институти као средства масовног информисања (СМИ) и образовни систем, и ствара се од стране водеће социјалне групе која израђује и политизује објективне културне карактеристике. Честа смена политичког статуса Придњестровља (у шта је могуће уверити се, полазећи од вишеизложеног) није могла да не утиче на етничку идентичност људи који живе у овом региону.

Културна политика мењала се сувише често и није успевала да постигне крајњи циљ, али ипак етничка идентичност свих група, које су живеле у Придњестровљу, мењала се у одређеном степену у складу са политиком претходних режима. Градски живот, без обзира на спровођену политику коренизације, остајао је под утицајем руског језика. Истовремено били су предузети кораци за замену националне културе и традиција совјетским. Као резултат, код Молдаваца, Украјинаца и Руса у Придњестровљу се појавило више заједничких карактеристика него што их је било код њих са сродним групама које су живеле ван граница региона.

Економске разлике између двеју обала учврстиле су осећај припадности разним идентичностима. Допринос Придњестровља републичком буџету МССР био је значајно већи од оних асигнација које су упућиване у развој тог 
региона. Неки порези, међу њима порез на земљу, били су у Придњестровљу двоструко виши него у Бесарабији. У време док је левообално становништво чинило 17\% укупног становништва Молдавије, а територија само 13\% републичке територије, у Придњестровљу се концентрисало 37\% индустријског потенцијала републике. Видевши такву несагласност, Придњестровци су сматрали да се развој Бесарабије остварује на рачун леве обале. [Бабилунга, Бомешко, 2002: с. 19].

Придњестровци су се мало интересовали за догађаје који су се дешавали у Бесарабији (после стварања МССР они су као и раније називали десну обалу овим термином, који је режим забранио). Омладина је претпостављала да добија више образовање не у Кишињеву, већ у Украјини или Русији. Одеса је за њих била привлачнији културни центар, него молдавска престоница Кишињев.

Све је то, са своје стране, утицало на формирање схватања света и менталитета становништва Придњестровља различито од „Бесарабљана”, и на тај начин на Левој обали настављала је да се образује особита регионална и етничка група људи, која се сједињавала и називала се народом Придњестровља.

Придњестровски Молдавци сматрали су се лојалнијим у односу на совјетски режим и политички поузданијим него Молдавци из бивше „буржоаске” Бесарабије; њима се давала предност у оквирима кадровске политике [Скворцова, 2003, с 61]. Одлив молдавске интелигенције из Придњестровља значајно је ослабио молдавски етнос и његову колективну идентичност на левој обали, што је учинило ту групу расположенијој ка асимилацији. Што се тиче Украјинаца, последње украјинске школе биле су затворене крајем 50-их година, тада су престале да излазе публикације на украјинском језику. Украјинци су били принуђени да користе руски језик, посебно у градовима, и молдавски у етнички мешовитим селима.

Немци су били репатрирани у Немачку у 1940. години, или послати у Сибир и Казахстан крајем 40-их, Пољаци су асимиловани, Јевреји су отишли ван граница. Руси су посредством активних контаката са другим локалним етничким групама, како у језичкој и културној сфери тако и у свакодневном животу, постали ближи локалном становништву него Русима који живе на северу Русије или у Сибиру, у свим совјетским републикама. Ситуација када матична група на својој територији не игра значајну улогу зато што је велики њен део представљен сеоским становништвом (Молдавци су чинили 60\% 
сеоског становништва и 25\% градског становништва Придњестровља) повољно је утицала на остварење совјетске националне политике, којој је било намењено да спроведе у живот идеју стварања у Совјетском Савезу јединствене наднационалне „нове историјске заједнице“, која се назива „совјетски народ".

Иако је совјетска национална политика усмерена на стварање нове идентичности - совјетског народа, била касније оцењена као неправилна, признато је да је у неким областима централно совјетско руководство постигло одређене успехе. Једна од таквих области било је Придњестровље, где су постојале потребне социјалне, културне и историјске претпоставке за остварење те политике. У то нас убеђује и чињеница да када је у Кишињеву 1988. године почео процес „националне обнове“, који је наредне године испољио очевидне прорумунске тенденције, Придњестровци су осетили непријатност. Ствар је у томе да су они били много ближи СССР-у и Русији као законитом правном следбенику Совјетског Савеза и хтели су да виде Кишињев на истој позицији. Придњестровци су категорички одбили да прихвате румунски триколор, који је у сећању још живих покољења асоцирао на најсуровији политички режим.

У тим околностима било је природно да је идеја стварања аутономије у Придњестровљу нашла широку подршку међу становништвом. Аутономија се посматрала као инструмент за заштиту совјетских вредности, за учвршћење јединства са СССР-ом и за заштиту Придњестровља од политике румунизације. Неприхватање молдавског национализма излило се у обнову совјетских вредности.

Приврженост СССР-у и Русији јасно је показала постојање друге идентичности Придњестроваца, и то да се регион разликује од Молдавије не само лингвистичком ситуацијом већ и етничким саставом становништва, историјом међуетничких односа и нивоом економског развоја. Стога се може смело тврдити да је у Придњестровљу довољно развијена регионална идентичност.

А како стоје ствари са формирањем етничке идентичности као саставног дела регионалне идентичности и у целини придњестровске?

По мишљењу савремених научника - политиколога, социолога, етнографа и етнолога, етничка идентичност су заједнички погледи које деле у одређеном степену чланови етничке групе, формирани у процесу узајамног деловања са другим етничким групама. Значајан део тих погледа 
резултат је спознаје заједничке историје, културе, традиција и територије [Бершин, 2002: с. 43]. Дата формулација може се применити на савремени развој придњестровског друштва.

Полазећи од свега горе реченог може се начинити следећи закључак: формирање придњестровског народа, као процес формирања придњестровске идентичности, постојало је, али се у условима стабилности одвијало споро. Када је пак настала опасност, претња од стране непријатеља, страх да већина оних вредности које су узгајане деценијама могу да буду предате у корист прорумунски расположеним националистима, процес учвршћења идентичности добио је нови подстрек и наставља да се развија до данас. Придњестровци теже да добију признање своје државности од стране светске заједнице, пре свега ради заштите својих етничких, социјалнополитичких и националних интереса и привилегија. А то се, као што је познато, може добити само заједно, осећајући се као јединствен народ.

\section{Литература}

Бабилунга, Бомешко, 2002 - Бабилунга Н.В., Бомешко Б.Г. Приднестровский конфликт: исторические, демократические, политические аспекты. Тирасполь, 1998. 222с.

Бершин, 2002 - Бершин Е. Дикое поле, Москва, 2002. 123с.

Доклад №13 Миссии ОБСЕ в Молдове, 1993 - Доклад №13 Миссии ОБСЕ в Молдове (13 ноября 1993г.) // Независимая Молдова, ноябрь, 1993

Кирошка, 1996 - Кирошка К. Война на Востоке Республики Молдова (1992):

Причины, факты, последствия // Arena Politicii. - 1996.- №1 - c. 12-14

Скворцова, 2003 - Скворцова А.Ю. Народ Приднестровья - собственная идентичность? // Ежегодный исторический альманах Приднестровья №7, Тирасполь, 2003, с. 58-66

Феномен Приднестровья, 2003 - Феномен Приднестровья, Тирасполь, 2003. 246c.

Laitin David, 1999 - Laitin David The Theory of the Political Identity // Ethnic Mobilization and Interethnic Integration - M.: TSIMO, 1999. 256c.

Превео с руског: Рајко Буквић 


\title{
FORMATION OF TRANSNISTRIAN IDENTITY IN CONDITIONS OF MULTINATIONAL COMMUNITY
}

\begin{abstract}
The article considers the problem of the existence and development of the Pridnestrovian identity. Different opinions and terms that determine its nature stimulated the author to answer the following questions: how and when did the Pridnestrovian identity form; what factors influenced its formation; what kind of identity is this - ethnic, regional, linguistic or other. Despite the controversy about the problem, the author concludes that the formation of the Pridnestrovian identity took place over decades, but it developed slowly in the conditions of political stability in the region. When the danger arose, the threat from the enemy, the fear that most of the values that had been cultivated for decades could be destroyed by pro-Romanian-minded nationalists of Moldova, the process of strengthening the Pridnestrovian identity received a new impetus and continues to develop today. Pridnestrovians are seeking to achieve recognition of their statehood by the international community, primarily to protect their ethnic, socio-political and national interests and privileges.

Keywords: Moldavian-Pridnestrovian conflict, Pridnestrovian identity; Pridnestrovian people; Pridnestrovian Moldavian Republic.
\end{abstract}

